\title{
Regional Trend in Ambient Air Quality Footprints in Calabar Urban, Nigeria
}

\author{
Josiah Nwabueze Obiefuna ${ }^{1, *}$, Gertrude Nnanjar Njar², Francis Ebuta Bisong ${ }^{1}$ \\ ${ }^{1}$ Department of Geography and Environmental Science, Faculty of Environmental Sciences, University of Calabar, P.M.B. 1115, \\ Calabar, Nigeria \\ ${ }^{2}$ Department of Surveying \& Geoinformatics, Faculty of Environmental Sciences, University of Calabar, P.M.B. 1115, Calabar, Nigeria
}

Received June 7, 2021; Revised July 13, 2021; Accepted August 22, 2021

\section{Cite This Paper in the following Citation Styles}

(a): [1] Josiah Nwabueze Obiefuna, Gertrude Nnanjar Njar, Francis Ebuta Bisong , "Regional Trend in Ambient Air Quality Footprints in Calabar Urban, Nigeria," Environment and Ecology Research, Vol. 9, No. 4, pp. 173 - 185, 2021. DOI: 10.13189/eer.2021.090405.

(b): Josiah Nwabueze Obiefuna, Gertrude Nnanjar Njar, Francis Ebuta Bisong (2021). Regional Trend in Ambient Air Quality Footprints in Calabar Urban, Nigeria. Environment and Ecology Research, 9(4), 173 - 185. DOI: 10.13189/eer.2021.090405.

Copyright@2021 by authors, all rights reserved. Authors agree that this article remains permanently open access under the terms of the Creative Commons Attribution License 4.0 International License

\begin{abstract}
Poor air quality is widely considered as one of the major environmental hazards confronting several urban centres worldwide. This study examined regional trend in ambient air quality footprints in Calabar Metropolis. Data on emission level of $\mathrm{CO}, \mathrm{NO}_{2}, \mathrm{SO}_{2}, \mathrm{H}_{2} \mathrm{~S}$, and $\mathrm{SPM}_{2.5}$ were collected using Crowcon Gasman, while point coordinates were collected using Garmin GPSMap 60CSx device. Interpolation algorithm in Geographic Information Systems infrastructure was used to generate the regional trend maps for the metropolis. Parametric analytical techniques such as Analysis of Variance (ANOVA) were employed to test the hypotheses, while descriptive statistics including tables, maps and standard deviation were also used to present the data based on the objectives of the study. The results of the trend surface analysis for the five (5) measured parameters show that $\mathrm{CO}$ and $\mathrm{SPM}_{2.5}$ were not significant at $\mathrm{P}>0.05$ with F-ratio of 0.99 and 2.45 respectively. Thus, the null hypothesis which states that there is no significant change in the regional trend in air quality across Calabar Metropolis was therefore accepted. Analysis for $\mathrm{NO}_{2}, \mathrm{SO}_{2}$ and $\mathrm{H}_{2} \mathrm{~S}$, were significant at $\mathrm{P}<0.05$ with F-ratio of 3.47, 3.35 and 7.79 respectively, causing the null hypothesis to be rejected. It was therefore recommended that mitigatory measures should be employed for the purpose of ensuring a sustainable, clean and green urban environment.
\end{abstract}

Keywords Regional Trend, Environmental Hazards,
Disasters, Air Quality, Pollution

\section{Introduction}

Air quality is the condition of air that defines its content level of one or more pollutants such as carbon dioxide $\left(\mathrm{CO}_{2}\right)$, nitrogen dioxide $\left(\mathrm{NO}_{2}\right)$, sulphur dioxide $\left(\mathrm{SO}_{2}\right)$, hydrogen sulphide $\left(\mathrm{H}_{2} \mathrm{~S}\right)$ and suspended particulate matter of $2.5 \mathrm{~mm}$ or higher in diameter, etc. The term 'air quality footprints' as used in this research denotes measurement, mathematical and graphical expression or depiction in area or land use based units, a set of green house gasses, pollutants or emissions accumulated within the life cycle of dominant economic activities across various land uses.

However, when land uses are not properly planned and adhered to, air quality would be affected. This condition would arise when large and numerous sources of emission such as industrial, commercial and transportation are located in close proximity to the residential areas or other air pollution-sensitive facilities such as schools. As a result of this, persons, communities and businesses affected would ultimately suffer negatively either in the form of higher costs of public health, higher mortality rate or higher pollution control cost.

The determination of air quality is often achieved by examining air pollutants emitted from anthropogenic activities as well as from nature. In order to improve air 
quality, control of human activities is very important rather than attempting to remove just air pollutants from the air [1].

Polluted air has been seen as one of the major environmental hazards confronting several urban centres worldwide. It has been proven that as cities grow numerically, physically and functionally, an increase in energy consumption, industrial effluents, and vehicular traffic becomes unavoidable. Ultimately, these would obviously impact negatively on the quality of air $[2,3]$. The Nigerian environment is continually, progressively and seriously susceptible to myriad of environmental issues such as pollution of water, air, land, erosion, climate change, global warming, biodiversity loss and desertification etc. Notably, air quality concern is principal focus for long term planning. With this, land is engaged and used in a way that minimizes emissions and exposure of the populace to a myriad of air pollutants.

\section{The Problematic}

Calabar metropolis is dynamic and as a result, varied economic activities are constantly emerging, causing pollution ranging from air and noise. In the metropolis, there appears to be gross inadequacy and lack of coordinated air quality assessment in spatial context. Assessing air quality in spatial context will give a clear picture of the spatial trend, which would be of immense benefit in air pollution attenuation. Several urban centres in Nigeria lack coordinated assessments of local air quality which should be one of the major tasks of the Federal Ministry of Environment or any other government body tasked with pollution control in the city [4]. Therefore, one of the disadvantages of inadequate air quality data is the inability to ascertain and link certain pollutants to a particular land use or to some economic activities within a land use in the metropolis. The ability to identify, predict behavior, map and link certain pollutants to certain land uses would invariably advocate adherence to proper land use planning or zoning regulations. Sule [5] supports the view that land use planning is to ensure that the best land is put to the best use, for the purpose of increasing profit and minimizing incompatibilities and conflicts arising from air and noise pollution.

Another implication of a deficiency of air quality data both on spatial scale is that it would be practically impossible to link certain health threatening and seasonal diseases to poor air quality. When data on air quality regional scale is grossly lacking, it would be impossible to link the prevalence of certain ailments to certain regional development and variability.

Another shortcoming of the inadequacy of air quality trend data is its implication on planning and policy formulation. For example, a leap towards greening of Calabar urban or any other urban area would first depend on available air quality data, which would give information on the most volatile and prevalent sources of air pollutants.

\section{Research Objectives}

The objective of this research was to examine the regional trend in ambient air quality footprints in Calabar metropolis, Nigeria

\section{Research Hypotheses}

$\mathrm{H}_{0}$ : There is no significant change in the regional trend in air quality footprints across Calabar Metropolis.

\section{The Study Area}

This study was carried out in the capital city Cross River State, known as Calabar (Figure 1). Calabar is located between longitudes $8^{\circ} 18^{\prime}$ and $8^{0} 25^{\prime \prime}$ East of the Greenwich meridian and latitudes $4^{\circ} 55^{\prime}$ and $5^{\circ} 10^{\prime}$ North of the Equator. It is sandwiched between the Great Kwa river to the East and the Calabar River to the west. Calabar Metropolis, which is made up of Calabar Municipality and Calabar South Local Government Area, covers an area of 1480 sqkms. Calabar is bounded to the North by Odukpani Local Government Area and to the East by Akpabuyo Local Government Area. 


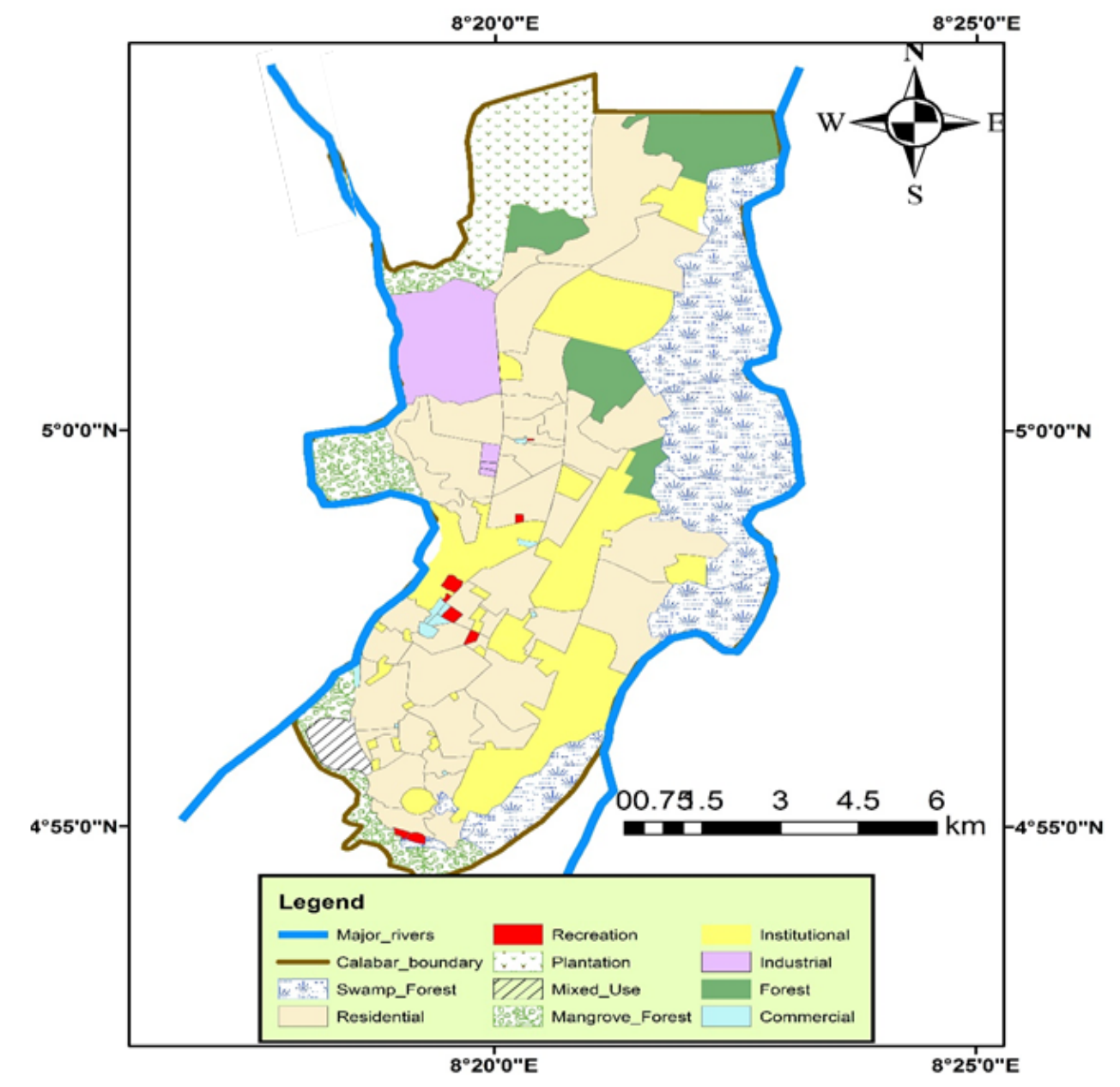

Source: Author`s GIS visualization, 2020.

Figure 1. Land use map of Calabar Metropolis showing the study area

\section{Method of Study}

Data for this study were made up of continuous variables in the form of air quality readings from various land uses such as industrial, transportation, commercial and residential. In a more specific term, the study relied on data on ambient air quality status in Calabar Metropolis, as well as data on seasonality differential in air quality status. The most commonly existing, harmful pollutants and particulate matters, as defined by the scope of this study, occasioned by predominant economic activities were measured. Data were expressed in parts per million (ppm) scale. Data of primary origin were acquired from various land uses in Calabar Metropolis. Data were acquired using relevant automated real-time data loggers such as Crowcon Gasman and a Garmin GPSMap. Such dataset included logged figures of main pollutants and particulate matter from various selected locations as well as the GPS coordinates for the locations. Another set of data consulted during this research was those of secondary origin. Examples of data in this group are the land use maps of the study area as well as the real-time Google earth imagine data.

During recognizance, GPS data were acquired using a
Garmin GPSmap 60CSx. It is digital equipment and consists of large, high resolution coloured liquid crystal display. The device was used to collect point coordinates for all the selected data points for the purpose of geo-referencing. Before operation, the power was activated by pressing and holding the power button. During the process of satellite signal acquisition by the GPS, a real time message "locating satellites" replaced by an "acquiring satellites" message appeared until enough signals were acquired to identify its location. When the receiver has adequate signals from at least three orbiting satellites, the unit's display changed to indicate position accuracy, elevation and as well, show other information about the location. However, to receive adequate satellite signals, the unit should be used outdoors, and have a clear view of the sky. Although it is small, the GPS is compact and very sensitive.

\subsection{Selection of Monitoring Sites and Data Collection}

During reconnaissance, decision for selecting monitoring sites within a land use considered parameters such as predominant economic activities, chemicals or physical interference, locality, terrain, services and local 
activities. Air quality test was carried out at each sample location within a land use using an automated, real-time air quality meter mounted on a ground-based platform, or held at a height of a range of between 1.5 and 2.0 meters from the ground. The choice of the height was based on the fact that the study was particularly interested in the ambience level of the pollutants. Data readings were made once between 12 noon and 12.30pm in the afternoon. The time period of choice represents peak period for most economic activities. Besides, the research is not focused on micro level but seasonal and land use based variation. Recording of data was done after 5 minutes delay for the equipment to fully adjust or internally calibrate to the new environment. Data collection lasted for a period of four months in two seasons. In the rainy (wet) season, readings were taken in the month of July and August. In the dry season, readings were taken in the month of November and December.

The most commonly existing, harmful pollutants and particulate matters occasioned by economic activities as stated in the scope were measured. Carbon monoxide has been identified as being very injurious to human health and the environment, while $\mathrm{PM}_{2.5}$ is said to be a causal agent for cancer, heart or respiratory disease [6].

\subsection{Sampling Procedure}

Stratification was employed to group and randomly select points from each land use for proper representation. On the transportation land use, 24 locations were identified. However, 7 locations were selected. Data were acquired from the road nodes or roundabouts along the major road networks and parks. In the industrial zone, data were acquired from both the minor road intersections within the zone as well as 10 metres from the pollution sources. A total of 18 locations were identified while five (5) locations were selected. In the commercial zones, data were acquired from the pollution sources after having identified them. A total of 22 locations were identified while 7 locations were selected. In the residential neighbourhood, data were acquired from minor road intersections as well as from other direct emission points. A total of 23 locations were identified while seven (7) locations were also selected. Table 1 shows a total of 26 representative samples representing 30 percent selected from all land uses using a row by column digital random number generator. This has been depicted (Figure 2).

\subsection{Urban Land use/Land Cover Classification Scheme}

In this research, a system of land use/land cover classification adapted from [7, 8] was adopted. For this study, attention was only be given to area occupied by settlements, companies, and infrastructures, otherwise known as the urban or built up area, as well as its sub classes such as the residential neighborhood (estates, housing quarters), commercial/services (market areas, buying and selling points within the urban area), transportation routes (road networks, airport, motor parks, bus terminals), and the industrial area (processing, fabrication, etc.).

\subsection{Techniques for Data Analysis}

Sourced data were subjected to analytical manipulations using GIS, as well as descriptive and inferential statistics. The output was in form of composite trend maps, averages, tables, charts and graphs. Besides, inferential statistics was also used to test the hypotheses. 
Table 1. Sampled points with their GPS coordinates

\begin{tabular}{|c|c|c|c|c|c|}
\hline $\begin{array}{l}\mathbf{S} / \\
\mathbf{N}\end{array}$ & Land use Type/ Location & Activity Type & $\begin{array}{l}\text { GPS } \\
\text { Lat. }\end{array}$ & $\begin{array}{l}\text { Value } \\
\text { Long. }\end{array}$ & Prevailing Activities/pollutants \\
\hline 1. & Industrial-EPZ & Administrative Block & 5.024907 & 8.322707 & Administrative Block \\
\hline 2. & Industrial-EPZ & $\begin{array}{l}\text { By Dangote Flour Mills, } \\
\text { Haulage, processing }\end{array}$ & 5.018985 & 8.322473 & $\begin{array}{l}\text { Processing, Haulage, vehicles, } \\
\text { trucks }\end{array}$ \\
\hline 3. & Industrial-EPZ & $\begin{array}{l}\text { M-Saleh Industry: } \\
\text { Fabrication, welding }\end{array}$ & 5.02485 & 8.32704 & $\begin{array}{l}\text { Point source: fabrication, welding, } \\
\text { metal cutting, smoothening, } \\
\text { welding. }\end{array}$ \\
\hline 4. & Industrial-EPZ & $\begin{array}{l}\text { Stone Craft Industry: } \\
\text { Processing }\end{array}$ & 5.02563 & 8.32704 & $\begin{array}{l}\text { Point source: Cutting and polishing } \\
\text { of stones, marble production }\end{array}$ \\
\hline 5. & Industrial-EPZ & $\begin{array}{c}\text { Rosa Mystica Tank farm, } \\
\text { Combination Industries: } \\
\text { processing }\end{array}$ & 5.028472 & 8.32248 & Tank farm, storage, processing \\
\hline 6. & $\begin{array}{l}\text { Transportation: Muritala } \\
\text { Muhammed highway }\end{array}$ & Road Node: Mobil by MCC & 4.98720 & 8.343341 & $\begin{array}{l}\text { Line sources: vehicles, dust } \\
\text { particles }\end{array}$ \\
\hline 7. & $\begin{array}{l}\text { Transportation } \\
\text { (Eleven-Eleven area) }\end{array}$ & Round About & 4.96384 & 8.32488 & $\begin{array}{l}\text { Line sources: vehicles, dust } \\
\text { particles }\end{array}$ \\
\hline 8. & $\begin{array}{l}\text { Transportation (Effio-Ette } \\
\text { area) }\end{array}$ & Round About & 4.993898 & 8.345098 & $\begin{array}{l}\text { Line sources: vehicles, dust } \\
\text { particles }\end{array}$ \\
\hline 9. & $\begin{array}{c}\text { Transportation (Etta-Agbor } \\
\text { Road) }\end{array}$ & $\begin{array}{c}\text { Round About (Unical Main } \\
\text { Gate) }\end{array}$ & 4.95254 & 8.33921 & $\begin{array}{l}\text { Line sources: vehicles, dust } \\
\text { particles }\end{array}$ \\
\hline 10. & $\begin{array}{c}\text { Transportation (Etta-Agbor } \\
\text { Road) }\end{array}$ & Round About (by IBB Rd & 4.95933 & 8.32164 & $\begin{array}{l}\text { Line sources: vehicles, dust } \\
\text { particles }\end{array}$ \\
\hline 11. & $\begin{array}{l}\text { Transportation (Ekpoabasi } \\
\text { Road) }\end{array}$ & Road Node by CRUTECH & 4.93151 & 8.3284 & $\begin{array}{l}\text { Line sources: vehicles, dust } \\
\text { particles }\end{array}$ \\
\hline 12. & Transportation (park) & Etim Edem park & 4.96039 & 8.3243 & $\begin{array}{l}\text { Line sources: vehicles, dust } \\
\text { particles }\end{array}$ \\
\hline 13. & $\begin{array}{c}\text { Commercial: Calabar Road } \\
\text { by Watt Market }\end{array}$ & By Atakpa Police Station & 4.95736 & 8.31927 & Buying and selling, vehicles \\
\hline 14. & $\begin{array}{l}\text { Commercial (Watt Market } \\
\text { Area) }\end{array}$ & By Nelson Mandela & 4.956593 & 8.32212 & Buying and selling, vehicles \\
\hline 15. & $\begin{array}{l}\text { Commercial (Watt Market } \\
\text { area) }\end{array}$ & By Goldie & 4.958283 & 8.32317 & Buying and selling, vehicles \\
\hline 16. & $\begin{array}{l}\text { Commercial (Watt Market } \\
\text { area) }\end{array}$ & $\begin{array}{l}\text { By Calabar road round } \\
\text { about }\end{array}$ & 4.957348 & 8.320463 & Buying and selling, vehicles \\
\hline 17. & $\begin{array}{l}\text { Commercial(Marian } \\
\text { Market) }\end{array}$ & Point source pollution & 4.9753 & 8.33922 & $\begin{array}{l}\text { Buying and selling, grinding, } \\
\text { vehicles }\end{array}$ \\
\hline 18. & $\begin{array}{l}\text { Commercial (Marian } \\
\text { Market) }\end{array}$ & Point source of pollution & 4.97559 & 8.33927 & $\begin{array}{l}\text { Buying and selling, vehicles, } \\
\text { grinding }\end{array}$ \\
\hline 19. & $\begin{array}{c}\text { Commercial: Marian Market } \\
\text { area }\end{array}$ & $\begin{array}{l}\text { Commercial activities, } \\
\text { waste dump }\end{array}$ & 4.976893 & 8.338185 & Buying and selling, vehicles, \\
\hline 20. & Residential: Ekorinim & $\begin{array}{l}\text { Residential: by Redeemed } \\
\text { Church }\end{array}$ & 4.99921 & 8.32295 & Residential, mobility \\
\hline 21. & Residential: Ekorinim II & Residential: By NPA & 4.999927 & 8.325983 & Residential, mobility \\
\hline 22. & Residential: Satellite town & $\begin{array}{l}\text { Residential: By Children of } \\
\text { Promise School }\end{array}$ & 4.959683 & 8.354402 & Residential, mobility \\
\hline 23. & Residential (State Housing) & $\begin{array}{l}\text { Residential:State Housing } \\
\text { by Atekon Drive }\end{array}$ & 4.980188 & 8.33551 & Residential, mobility \\
\hline 24. & Residential (State Housing) & By the police Station & 4.98532 & 8.33952 & Residential, mobility \\
\hline 25. & $\begin{array}{l}\text { Residential (Federal } \\
\text { Housing) }\end{array}$ & $\begin{array}{l}\text { Residential: By Esien } \\
\text { Kooffreh/Police Station }\end{array}$ & 5.021298 & 8.336463 & Residential, mobility \\
\hline 26. & $\begin{array}{l}\text { Residential (Federal } \\
\text { Housing) }\end{array}$ & Residential & 5.029147 & 8.335152 & Residential, mobility \\
\hline
\end{tabular}

Source: Author’s fieldwork, 2020 


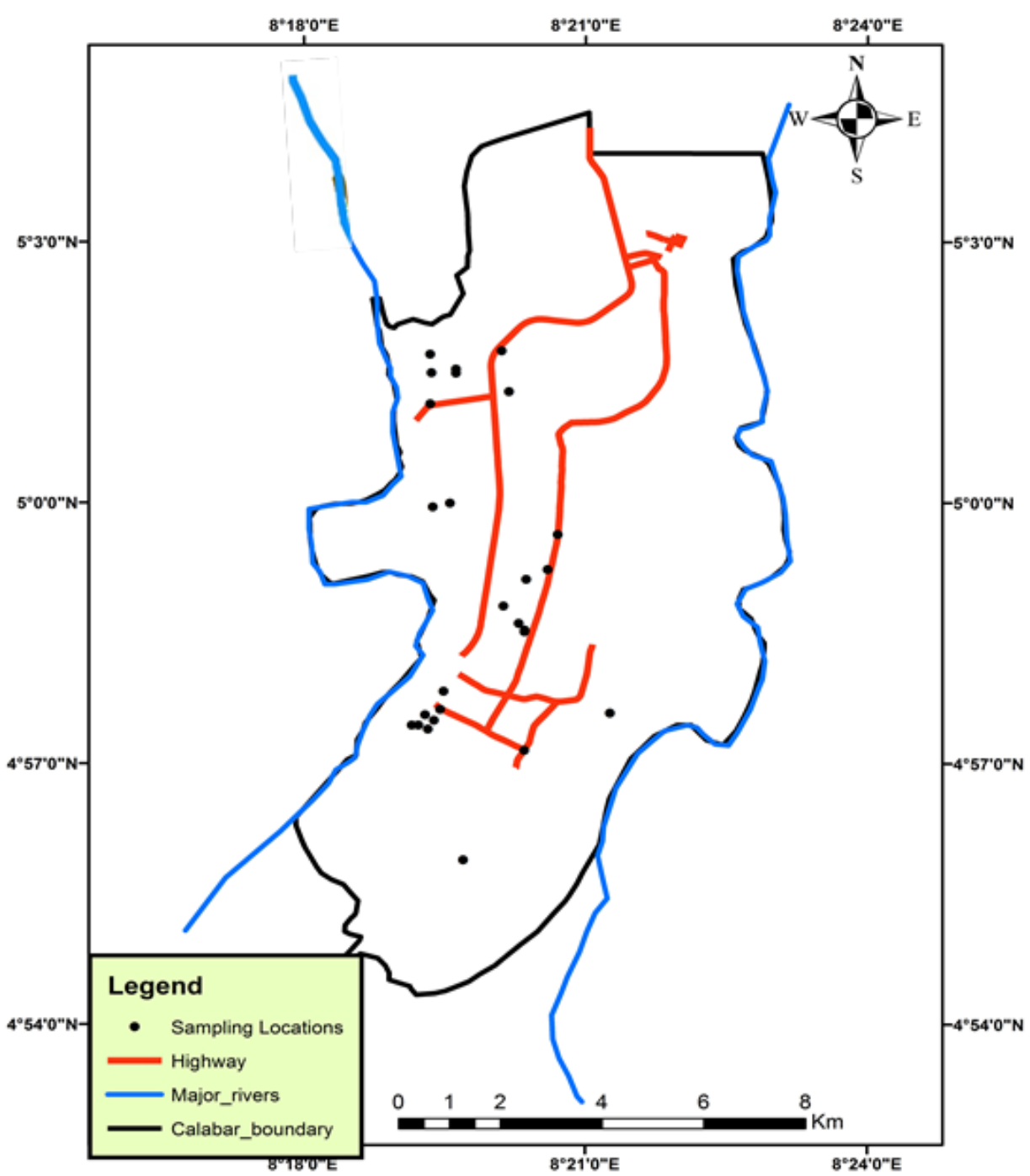

Source: Author`s GIS visualization, 2020.

Figure 2. Sampled locations across land uses in Calabar Metropolis

\section{Test of Hypothesis}

$\mathrm{H}_{0}$ : There is no significant change in the regional trend in air quality across Calabar Metropolis.

$\mathrm{H}_{1}$ : There is a significant change in the regional trend in air quality across Calabar Metropolis.

The linear trend surface analysis was used in testing the hypothesis. The trend surface analysis is important in geospatial studies as it enables the researcher to segregate any spatially distributed variables into a broad system pattern of variation (regional trend) and random nonsystematic variables (local component). By adopting the linear trend in this work, it was assumed that the gradient between any two points on the map of the distribution approximates a straight line. The regional trend which is of interest to the researcher in the present study is expressed by the following equations:

$$
\mathrm{Z}=\mathrm{a}+\mathrm{b}(\mathrm{x})+\mathrm{c}(\mathrm{y})
$$

Where $\mathrm{Z}$ is the value of the variable being mapped ( $\mathrm{CO}$,
$\mathrm{NO}_{2}, \mathrm{SO}_{2}, \mathrm{H}_{2} \mathrm{~S}$, and SPM 2.5), $\mathrm{X}$ is the Eastings, while $\mathrm{Y}$ is the Northings. Actually, this is a multiple regressing equation of the independent variables. The normal equation can be expressed as follows:

$$
\begin{gathered}
a N+b \sum X+c \sum y=\sum Z \\
a \sum X+b \sum X^{2}+c \sum X Y=\sum Z X \\
a \sum y+b \sum X Y+c \sum Y^{2}=\sum Z Y
\end{gathered}
$$

The results of the regional trend are shown in graphs, while the f-ratio was used to test the significance of the trend for each of the variables.

\subsection{Assessment of Regional Trend Surface Analysis of Ambient Air Quality Footprints in Calabar Metropolis}

$\mathrm{H}_{0}$ : There is no significant change in the regional trend in air quality across Calabar Metropolis. 
$\mathrm{H}_{1}$ : There is a significant change in the regional trend in air quality across Calabar Metropolis.

The result of the trend surface analysis for the five measured parameters is shown both in graphical and statistical forms. The differential data has been presented (Appendix 1). Table 2 presents the result of the analysis, while figures 3, 4, 5, 6 and 7 show the regional trends of the air quality footprints in Calabar Metropolis. For example, figure 3 shows the direction of distribution of CO level. The concentration of CO is high in the North East area (red) but low in the South West direction of the chart (green). Same interpretation is applicable to the rest of the trend maps. The regional trend model for each of the parameters is given as follows:

$$
\begin{aligned}
& \mathrm{CO}: \mathrm{Z}=32.27+0.12 \mathrm{x}+0.08 \mathrm{y} \\
& \mathrm{NO}_{2:} \mathrm{Z}=41.12+0.25 \mathrm{x}+0.10 \mathrm{y} \\
& \mathrm{SO}_{2:} \mathrm{Z}=33.70+0.27 \mathrm{x}+0.05 \mathrm{y}
\end{aligned}
$$

$$
\begin{gathered}
\mathrm{H}_{2} \mathrm{~S}: \mathrm{Z}=5.55+0.44 \mathrm{x}+0.14 \mathrm{y} \\
\text { SPM 2.5: } \mathrm{Z}=86.3+0.05 \mathrm{x}+0.23 \mathrm{y} .
\end{gathered}
$$

\begin{tabular}{|c|c|c|c|c|c|}
\hline Parameters & $\begin{array}{c}R^{2} \\
(\%)\end{array}$ & d.f & F-ratio & $\mathbf{P}$ & Remarks \\
\hline $\mathrm{CO}$ & 3 & 2,75 & 0.99 & $>0.05$ & $\begin{array}{c}\text { Not } \\
\text { significant, } \\
\text { accept } \mathrm{H}_{0}\end{array}$ \\
\hline $\mathrm{NO}_{2}$ & 9 & 2,75 & 3.47 & $<0.05$ & $\begin{array}{l}\text { Significant, } \\
\text { reject } \mathrm{H}_{0}\end{array}$ \\
\hline $\mathrm{SO}_{2}$ & 8 & 2,75 & 3.35 & $<0.05$ & $\begin{array}{l}\text { Significant, } \\
\text { reject } \mathrm{H}_{0}\end{array}$ \\
\hline $\mathrm{H}_{2} \mathrm{~S}$ & 17.6 & 2,75 & 7.79 & $<0.05$ & $\begin{array}{l}\text { Significant, } \\
\text { reject } \mathrm{H}_{0}\end{array}$ \\
\hline SPM 2.5 & 6.3 & 2,75 & 2.45 & $>0.05$ & $\begin{array}{c}\text { Not } \\
\text { significant, } \\
\text { accept } \mathrm{H}_{0}\end{array}$ \\
\hline
\end{tabular}

Table 2. Summary result of the trend surface statistics

. Source: Author’s analysis, 2020.

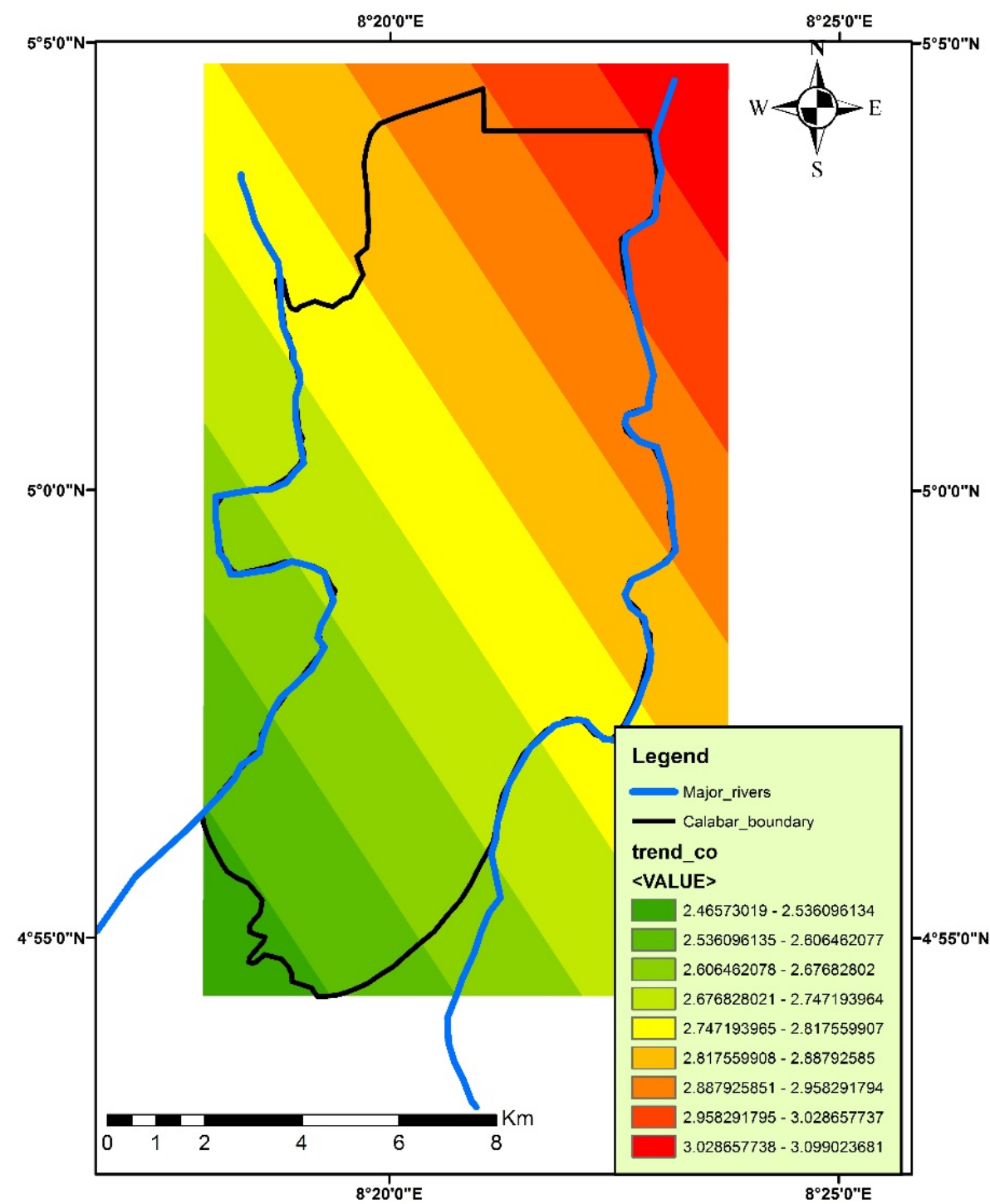

Source: Author`s GIS visualization, 2020.

Figure 3. Regional trend in $\mathrm{CO}$ across Calabar Metropolis 


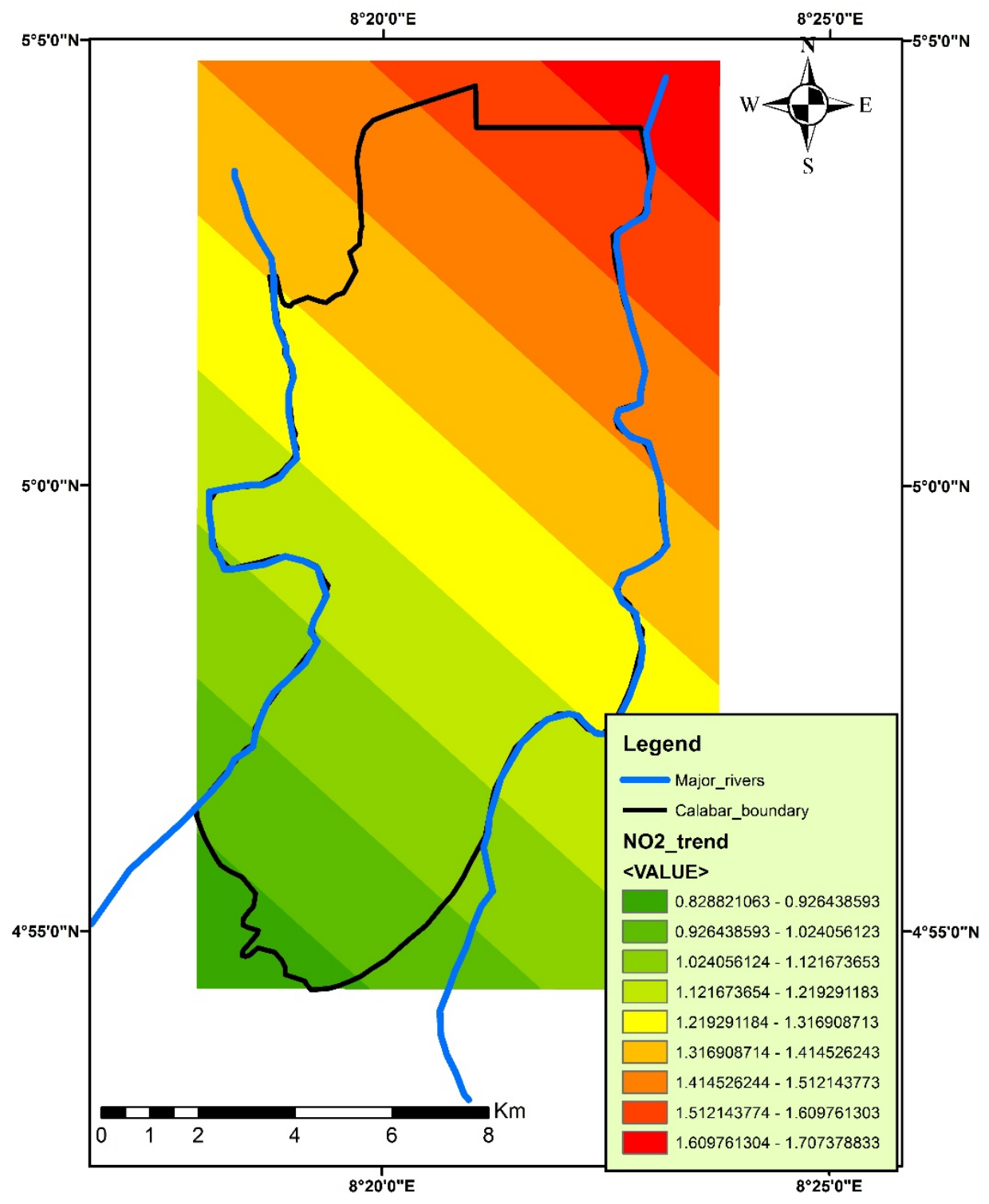

Source: Author`s GIS visualization, 2020.

Figure 4. Regional trend in $\mathrm{NO}_{2}$ across Calabar Metropolis 


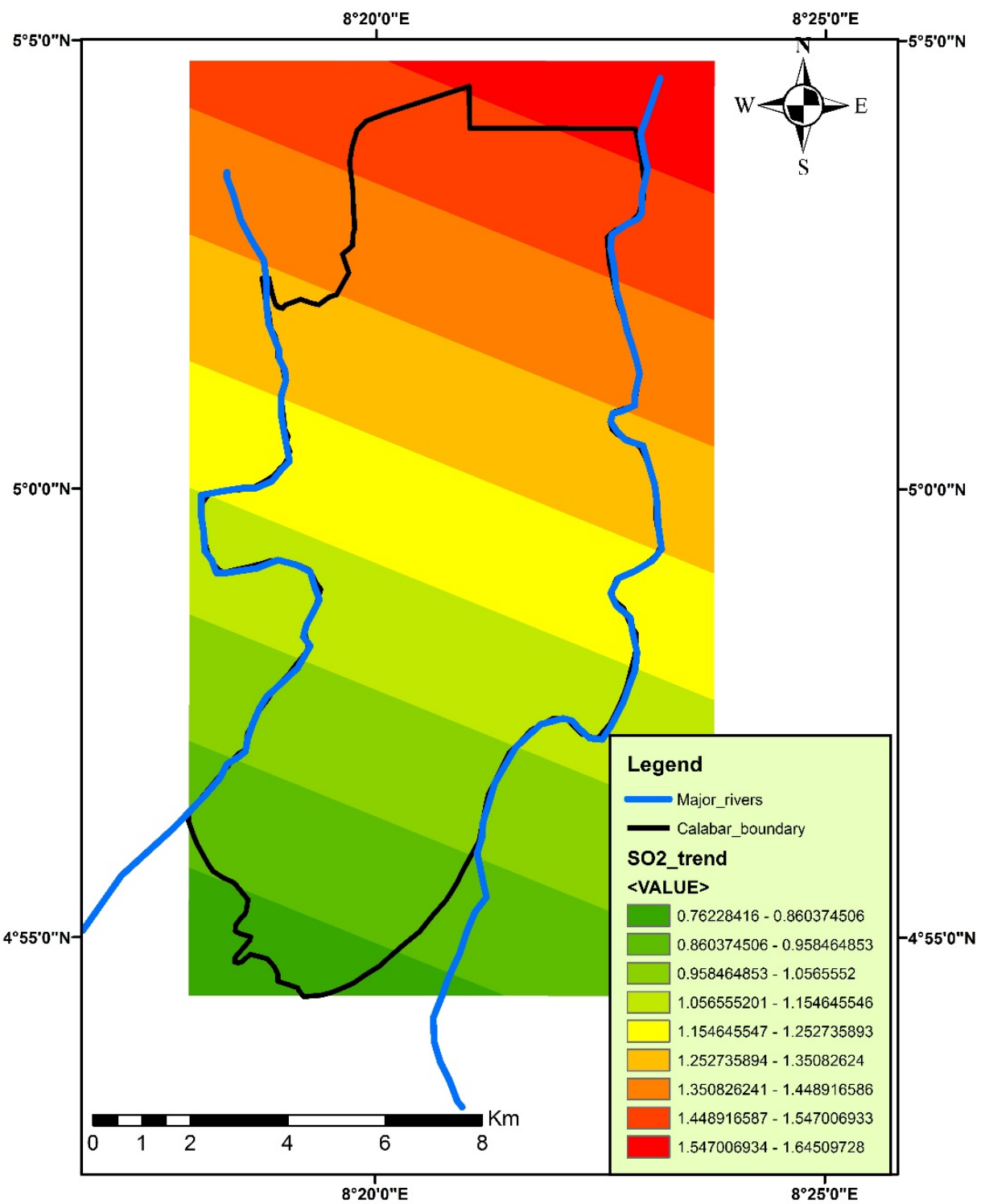

Source: Author`s GIS visualization, 2020.

Figure 5. Regional trend in $\mathrm{SO}_{2}$ across Calabar Metropolis 


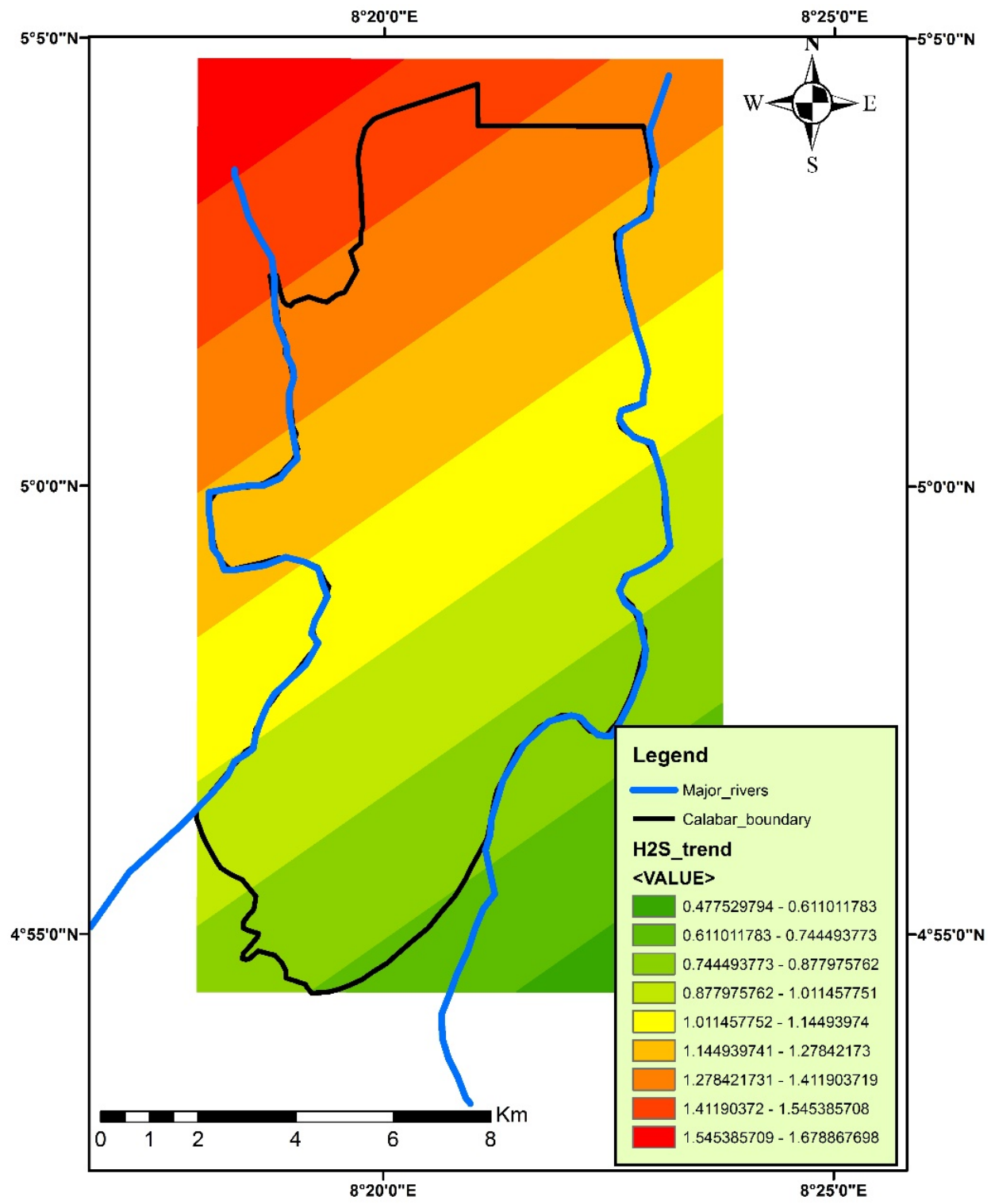

Source: Author`s GIS visualization, 2020.

Figure 6. Regional trend in $\mathrm{H}_{2} \mathrm{~S}$ across Calabar Metropolis 


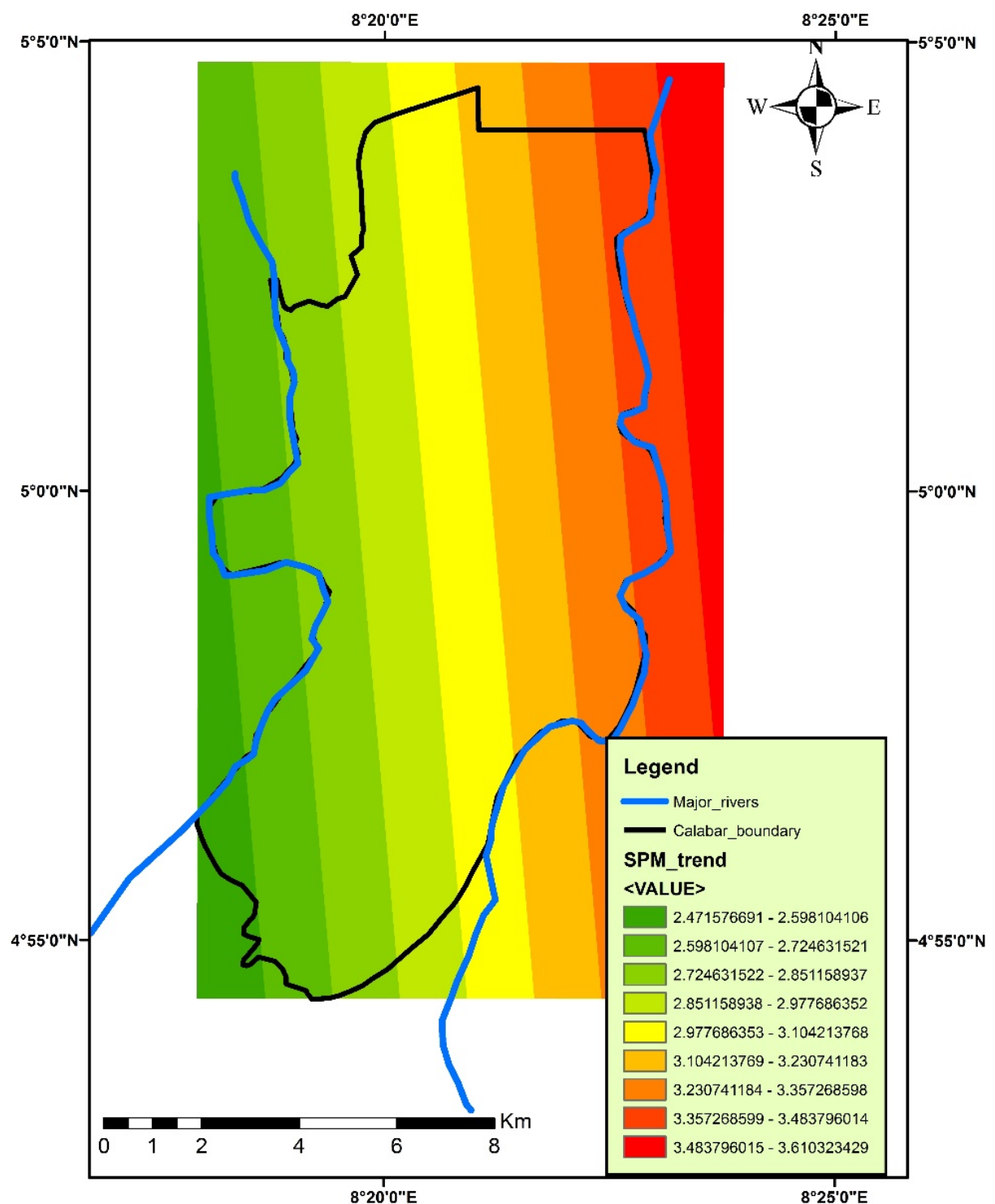

Source: Author`s GIS visualization, 2020.

Figure 7. Regional trend in $\mathrm{SPM}_{2.5}$ across Calabar Metropolis

\section{Summary}

The study examined regional trend in ambient air quality across Calabar Metropolis. The analytical techniques took both geospatial and statistical dimensions. The outputs are in the form of 5 composite maps out of which five depicts regional trends for the measures parameters; as well as the results of the tests of hypotheses.

The hypothesis examined the nature of significance in spatial trend in air quality across Calabar Metropolis. The result of the trend surface analysis for the five (5) measured parameters show that $\mathrm{CO}$ and $\mathrm{SPM}_{2.5}$ were not significant at $\mathrm{P}>0.05$ with F-ratio of 0.99 and 2.45 respectively. Thus, the null hypothesis which states that there is no significant change in the regional trend in air quality across Calabar Metropolis was therefore accepted. Analysis for $\mathrm{NO}_{2}, \mathrm{SO}_{2}$ and $\mathrm{H}_{2} \mathrm{~S}$, were significant at $\mathrm{P}<0.05$ with F-ratio of 3.47, 3.35 and 7.79 respectively, causing the null hypothesis to be rejected.

\section{Conclusions}

The spatial trend in ambient air quality footprint in Calabar urban has been examined. The study has been able to unearth serious deterioration of ambient air quality status in the area as air pollution has been found to be a prevalent issue associated with anthropogenic activities being undertaken in the metropolis. Thematic composite maps were generated, while hypothesis was also tested. The hypothesis proved that test of $\mathrm{CO}$ and $\mathrm{SPM}_{2.5}$ were 
not significant at $\mathrm{P}>0.05$ with F-ratio of 0.99 and 2.45 respectively causing the null hypothesis to be accepted. Analysis for $\mathrm{NO}_{2}, \mathrm{SO}_{2}$ and $\mathrm{H}_{2} \mathrm{~S}$, were significant at $\mathrm{P}<0.05$ with F-ratio of $3.47,3.35$ and 7.79 respectively, causing the null hypothesis to be rejected.

\section{Recommendations}

Based on the findings of this research, certain mitigatory measures are therefore recommended for the purpose of ensuring a sustainable, clean and green Calabar Metropolis.

1. Green areas, open spaces and gardens should be well maintained, preserved and protected due to their potentials in sanitizing the air by acting as green lungs.

2. Finally, a more comprehensive research which would cut across the 12 calendar months should be undertaken on this theme.

\section{APPENDIX 1}

\section{Seasonal Differential in air pollutants}

\begin{tabular}{|c|c|c|c|c|c|c|c|c|c|c|}
\hline \multirow[t]{2}{*}{ DAY } & \multicolumn{5}{|c|}{ WET SEASON } & \multicolumn{5}{|c|}{ DRY SEASON } \\
\hline & CO & $\mathrm{NO}_{2}$ & $\mathrm{SO}_{2}$ & $\mathbf{H}_{2} \mathrm{~S}$ & SPM2.5 & CO & $\mathrm{NO}_{2}$ & $\mathrm{SO}_{2}$ & $\mathbf{H}_{2} \mathrm{~S}$ & SPM2.5 \\
\hline 1 & 2.42 & 0.70 & 1.24 & 0.80 & 3.02 & 3.07 & 1.08 & 1.29 & 1.23 & 3.76 \\
\hline 2 & 2.44 & 0.70 & 1.27 & 0.78 & 3.02 & 3.07 & 1.08 & 1.28 & 1.22 & 3.77 \\
\hline 3 & 2.45 & 0.69 & 1.26 & 0.79 & 3.01 & 3.18 & 1.16 & 1.30 & 1.22 & 3.82 \\
\hline 4 & 2.44 & 0.71 & 1.24 & 0.79 & 3.00 & 3.14 & 1.16 & 1.29 & 1.25 & 3.82 \\
\hline 5 & 2.42 & 0.71 & 1.23 & 0.78 & 2.99 & 3.12 & 1.17 & 1.31 & 1.25 & 3.83 \\
\hline 6 & 2.41 & 0.71 & 1.21 & 0.78 & 3.02 & 3.18 & 1.19 & 1.34 & 1.25 & 3.88 \\
\hline 7 & 2.42 & 0.68 & 1.13 & 0.77 & 2.97 & 3.17 & 1.21 & 1.35 & 1.27 & 3.84 \\
\hline 8 & 2.37 & 0.68 & 1.14 & 0.76 & 2.96 & 3.17 & 1.21 & 1.36 & 1.29 & 3.83 \\
\hline 9 & 2.41 & 0.68 & 1.27 & 0.76 & 2.98 & 3.24 & 1.21 & 1.37 & 1.30 & 3.87 \\
\hline 10 & 2.40 & 0.68 & 1.21 & 0.74 & 2.99 & 3.24 & 1.23 & 1.40 & 1.31 & 3.91 \\
\hline 11 & 2.42 & 0.68 & 1.21 & 0.76 & 2.99 & 3.25 & 1.24 & 1.41 & 1.32 & 3.93 \\
\hline 12 & 2.42 & 0.67 & 1.20 & 0.75 & 2.97 & 3.24 & 1.27 & 1.42 & 1.34 & 3.95 \\
\hline 13 & 2.40 & 0.65 & 1.23 & 0.73 & 3.06 & 3.25 & 1.28 & 1.43 & 1.35 & 3.94 \\
\hline 14 & 2.32 & 0.65 & 1.16 & 0.72 & 2.93 & 3.30 & 1.29 & 1.45 & 1.36 & 3.95 \\
\hline 15 & 2.31 & 0.64 & 1.20 & 0.71 & 2.91 & 3.32 & 1.29 & 1.46 & 1.37 & 3.95 \\
\hline 16 & 2.36 & 0.64 & 1.18 & 0.71 & 2.92 & 3.41 & 1.31 & 1.47 & 1.38 & 4.00 \\
\hline 17 & 2.37 & 0.64 & 1.11 & 0.70 & 2.90 & 3.36 & 1.32 & 1.48 & 1.38 & 4.02 \\
\hline 18 & 2.35 & 0.63 & 1.15 & 0.70 & 2.87 & 3.37 & 1.32 & 1.49 & 1.44 & 4.05 \\
\hline 19 & 2.33 & 0.64 & 1.12 & 0.70 & 2.86 & 3.39 & 1.34 & 1.50 & 1.46 & 4.05 \\
\hline 20 & 2.33 & 0.62 & 1.11 & 0.70 & 2.83 & 3.34 & 1.34 & 1.51 & 1.48 & 4.05 \\
\hline 21 & 2.28 & 0.60 & 1.08 & 0.68 & 2.81 & 3.33 & 1.36 & 1.52 & 1.48 & 4.05 \\
\hline 22 & 2.26 & 0.60 & 1.07 & 0.68 & 2.83 & 3.43 & 1.36 & 1.55 & 1.45 & 4.09 \\
\hline 23 & 2.32 & 0.60 & 1.08 & 0.68 & 2.82 & 3.43 & 1.39 & 1.56 & 1.46 & 4.11 \\
\hline 24 & 2.30 & 0.59 & 1.09 & 0.68 & 2.81 & 3.46 & 1.35 & 1.57 & 1.47 & 4.13 \\
\hline 23 & 2.28 & 0.59 & 1.07 & 0.67 & 2.78 & 3.47 & 1.36 & 1.58 & 1.48 & 4.14 \\
\hline 26 & 2.26 & 0.57 & 1.12 & 0.65 & 2.82 & 3.56 & 1.36 & 1.59 & 1.49 & 4.16 \\
\hline 27 & 2.28 & 0.56 & 1.05 & 0.65 & 2.74 & 3.51 & 1.36 & 1.60 & 1.54 & 4.16 \\
\hline 28 & 2.23 & 0.55 & 1.06 & 0.65 & 2.73 & 3.51 & 1.38 & 1.61 & 1.51 & 4.15 \\
\hline 29 & 2.21 & 0.53 & 1.07 & 0.64 & 2.73 & 3.53 & 1.40 & 1.62 & 1.52 & 4.25 \\
\hline 30 & 2.18 & 0.52 & 1.04 & 0.64 & 2.73 & 3.56 & 1.40 & 1.63 & 1.50 & 4.22 \\
\hline 31 & $* 2.17$ & $* 0.52$ & $* 1.05$ & $* 0.63$ & $* 2.70$ & *1.93 & $* 0.79$ & $* 0.92$ & $* 0.86$ & *2.32 \\
\hline
\end{tabular}

*Values were not considered during analysis

Source: Author’s fieldwork, 2020. 


\section{REFERENCES}

[1] Sangheon, L. \& Kyushik, O. "An analysis of the relationship between air pollutants and urban characteristics using the trajectory model: The case of Seoul, Korea”. International Journal of Environmental Science and Development, Vol. 3 No. 5, pp. 475-479, 2012.

[2] Faniran, A. \& Adeboyejo, A.T. "Environmental education and awareness for effective environmental protection and management in Nigeria”. Journal of the Nigeria Institute of Town Planners, Vol. 12, pp. 1-13, 1999.

[3] Kahyaoglu-Koracin, J., Basset, S. D., Mouat, D. A. \& Gertler, A.W “Application of a scenario-based modeling system to evaluate the air quality impacts of future growth". Atmospheric Environment, Vol. 43, pp. 1021-1028, 2009.

[4] Olowoporoku, D. "How clean is the air Nigerians breathe?a case for national air quality management framework". Air Quality Management Resource Centre, Bristol, UK. http://nigeriaworld.com/articles/2011/feb/012.html/ (assessed $18^{\text {th }}$ October, 2020.)

[5] Sule, R. O. "Planning Urban facilities for Environmental Quality in Fundamentals of urban planning: Theory and practice in Nigeria.” Lagos: BAAJ Intl, 2003. pp. 1-174

[6] Stephen, D. S. \& Sundar, A. C. "Exploring land use and land cover effects on airquality in Central Alabama using GIS and remote sensing”. Remote Sensing, Vol. 3, pp. 2552-2567, 2011.

[7] Anderson, J. R., Hardy, E. E., Roach, J. T. \& Witmer, R. E. "Landuse and land cover classification system for use with remote sensing data. Geological survey professional paper 964”, Washington DC: USA, pp. 1-26, 1976.

[8] Efiong-Fuller, E. “An unpublished monograph of remote sensing and cartography with course outline and manual for practical exercises” pp 1-24, 2004. 